\title{
AGAMA DAN SEKULERISME Kematian Sekulerisme Dalam Perspektif Aksi Bela Islam
}

\author{
Ginanjar Kartasasmita \\ Program Magister Religious Studies pascasarjana UIN Sunan gunung Djati Bandung Jl.A.H Nasution 105 Cibiru, \\ Bandung 40614.Indonesia E-Mail: ginanjar@gmail.com
}

\begin{abstract}
This article will discuss about the real phenomenon that occurred in the Islamic community in Indonesia, the act of defending Islam became a symbol of the emergence of the spirit of Islamization that is sweeping this nation, the Islamic belief to break the movement of secularism that swept many countries with the majority of the population of Islam in a few years, but the Islamic defenses show that Islamic society in Indonesia has risen.
\end{abstract}

Keywords:

Secularism; Resurrection; Death.

\begin{abstract}
Abstrak
Artikel ini akan membahas tentang fenomena nyata yang terjadi pada masyarakat Islam di Indonesia, tindakan membela Islam menjadi simbol munculnya semangat islamisasi yang menyapu bangsa ini, kepercayaan Islam untuk mematahkan gerakan sekularisme yang menyapu. banyak negara dengan mayoritas penduduk Islam dalam beberapa tahun saja, tapi pertahanan Islam menunjukkan bahwa masyarakat Islam di Indonesia telah bangkit.
\end{abstract}

Kata Kunci:

Sekularisme; Kebangkitan; Kematian.

\section{A. PENDAHULUAN}

Akhir-akhir ini term agama menjadi issue yang menarik untuk diperbincangkan baik agama sebagai pemahaman maupun agama sebagai politik, Media masa baik itu cetak maupun itu elektronik issue agama menjadi trending topic. Apalagi terjadinya Demonstrasi gelar Bela Islam yang diprakarsai oleh lembaga tertinggi salah satu agama besar di Indonesia yakni MUI (Majelis Ulama Indonesia) dan GNPF-MUI.

Demontrasi besar-besaran berlangsung pada 4 Nopember 2016 Penggeraknya menamakan diri Gerakan Nasional Pengawal Fatwa MUI (GN- PF-MUI). Demonstran menuntut agar aparat hukum segera memproses kasus dan mempidana penista agama, yang menuntut fatwa MUI bertanggal 11 Oktober 2016 atas perkara yang telah dilakukan oleh Basuki Tjahaja Purnama alias Ahok. ${ }^{1}$ Jutaan Orang

${ }^{1}$ Dede Mulyanto "Bela Islam atau Bela Oligarki : Pertalian Agama Politik dan Kapitalisme di Indonesia "Pustaka Indoprogres", 2017. Sebuah Pengantar. tergerak Hatinya dan Ratusan ribu orang turun ke jalan yang berpusat di daerah DKI Jakarta. Tak cuma ulama dan umat kebanyakan, semua elemen masyarakat ikut tergerak hatinya mulai dari kalangan bawah hingga kalangan atas.

Melihat dari fenomena itu issue agama menjadi sangat seksi untuk diperbincangkan, bahkan menjadi sebuah hal yang sangat menakutkan jika dipelesetkan, di bangsa tercinta ini Agama menjadi sebuah kemelekatan dalam diri setiap individu bahkan Agama sangat dipandang sebuah jati diri tersendiri, terbukti dengan terdapatnya Kolom Agama di Kartu Tanda Penduduk yang menegaskan jika Agama adalah simbol masyarakat yang konon ber-Bhineka Tunggal Ika, dari arti Agama sendiri menurut KBBI ialah ajaran atau sistem yang mengatur tata keimanan (kepercayaan) dan peribadatan kepada Tuhan Yang Mahakuasa serta tata kaidah yang berhubungan dengan pergaulan manusia dan manusia, serta lingkungannya. ${ }^{2}$

${ }^{2}$ http://kbbi.web.id/agama di Unduh pada tanggal 16 Maret 2017, Pukul: 08:00 WIB 
Maka terlihat jelas arti dari Agama adalah semacam aturan yang berasfek kesalihan social, namun apabila sebuah agama yang bersifat individu dan yang ditinggikan hanya segelintir Manusia kemudian dilegitimasi oleh sebuah kelompok dan akhirnya menjadi sebuah peng-klaiman kebenaran dan memaksa kepada setiap orang untuk memaksakan sebuah ajaran tertentu, maka tentu saja ini menjadi sebuah ancaman tersendiri.

Namun jika dilihat dari kejadian Aksi bela Islam yang terjadi tahun 2016 hingga awal tahun 2017 kemarin ini menunjukan sikap kebersamaan muncul dan semangat yang diusung seolah satu tanpa sekte, tanpa perbedaan.

Sebagian kaum nasionalis mengatakan jika aksi bela islam adalah symbol kebangkitan Islam di Indonesia, dan ini terbukti dengan mulai merebaknya berbagai kasus yang ditujukan kepada para pemimpin dalam pergerakan bela islam tersebut bahkan dengan membuat sebuah aturan pembubaran ormas yang dinilai mengancam NKRI.

Terbukti ada beberapa kesan yang dimunculkan pasca kejadian bela islam tersebut diantarnya pengalihan issue Politik PILKADA DKI Jakarta dan hingga issue PILPRES 2019, komentar yang bermacam-macam dari kalangan politikus yang menakuti kekuatan dan semangat umat Islam yang begitu luar biasa akhirnya menuaikan hasil dengan mulai membuat wacana tentang peraturan yang bersifat Konstitusional dengan membuat peraturan pendataan ulama atau sertifikasi Mubaligh.

Suasana semacam ini dinilai berdampak buruk bagi semua pemeluk Agama, karena dihinggapi oleh rasa kebencian dan rasa kecurigaan yang amat mendalam, hal inilah yang menurut hemat saya dinilai pemerintah ingin membedakan antara Agama dan Pemerintahan, seperti idealnya sebuah Negara atau pemerintahan yang bersifat Republik berarti mau tidak mau menina bobo kan dulu konteks Agama atau mengkesampingkan issue agama karena dinilai bersifat sensitive bagi sebuah keutuhan Negara tersebut.
Negara kita yang menurut orang dinilai sebagai mayoritas Muslim terbanyak di dunia malah memegang teguh konsep Republik atas nama kemanusiaan dan kesatuan karena seperti halnya Negara kita berasumsi bahwa Agama kemungkinan akan menjadi sebuah pedang yang memiliki dua ujung mata pedang, yang satu akan menghunus musuh dan yang satu lagi akan melukai si pemain pedang itu jika tidak pandai memainkannya, maka pada Tahun 1945 negara kita tidak memilih menjadi Negara Islam walau menurut sebagian berpendapat jika mayoritas para pahlawan yang memperjuangkan NKRI adalah dari kalangan Muslimin dan muslimat. ${ }^{3}$ Namun kenyataannya dalam proklamasi menyatakan jika Negara kita menjadi Negara Kesatuan Republik Indoneisa.

Dalam arti lain Negara kita memilih berhaluan Sekuler ketimbang mendirikan Negara ber Asaskan Agama, pertimbangannya adalah jika kita berasaskan salah satu Agama maka kemudian kita secara otomatis membuat sekat dengan Agama lainnya dan ini bisa berakibat fatal, yang mana kerukunan dan persatuan tidak akan pernah tercipta dan ketentraman negarapun mungkin akan terganggu dan yang terjadi jika Negara terlalu mencampuri urusan Agama begitupun sebaliknya maka tidak heran satu sama lain akan saling intervensi dan saling bersebrangan.

Maka dalam tulisan ini saya akan menitik beratkan bagaimana kaitan Agama dengan Negara dalam persfektip Sekulerisme.

\section{B. HASIL DAN PEMBAHASAN}

\section{Memahami Sekulerisme dan Sekulerasi}

Sekuler, dalam kamus bahasa dapat diartikan sebagai bersifat duniawi atau kebendaan (bukan bersifat keagamaan atau kerohanian). ${ }^{4}$ Sekularisasi jika dalam artian bahasa Indonesia, berasal dari kata dalam bahasa Inggris secularization, yang berawal dari

3 George McT. Kahin "Menuju Masyarakat Egalitarian: tentang Revolusi Kemerdekaan" kumpulan artikel Mencari Demokrasi, institute Studi Arus Informasi, (PT Midas surya grafindo:199)

4 http://kbbi.web.id/sekuler diunduh pada tanggal 16 Maret 2017, pukul 18.00 WIB. 
bahasa Latin saeculum yang diartikan sebagai the temporal world (dunia temporal) sebagai lawan dari the Kingdom of God (Ke-rajaan Tuhan $)^{5}$ Sekularisasi seringkali diasumsikan dan berhubungan erat secara bersamaan dengan modernisasi. Modernisasi di sini diartikan dengan pembalikkan pusat dan nilai lama kedalam nilai kekinian, dengan contoh kosmosentrisme digantikan antroposentrisme Selanjutnya menurut al-Attas, kemunculan pemahaman sekular telah dimulai pada abad ke- 13M. Pada saat itu orang Barat mulai memahami sekuler dengan menekankan sisi humanitas. ${ }^{6}$ Hingga Pandangan sekular itu berlanjut pada abad ke-15 sampai abad ke-16, yang dalam sejarah Barat dikenal dengan Abad "Renaissance" Abad Pencerahan.

Pada Abad ini ditandai dengan hilangnya semangat orang Barat terhadap agama Kristen karena agama Kristen dinilai terlalu banyak penekanan yang tidak sesuai dengan bahasa kemanusiaan dan jauh dari kata pengetahuan. Mereka lebih tertarik kepada pencarian ilmu pengetahuan dan mulai memhidupkan kembali tradisi peradaban Yunani kuno yang telah mereka lupakan. Semangat itu terus berakar hingga meruncing sampai tahap ekstrimnya pada abad ke17 sampai abad ke-19 di Eropa, yang dikenal sebagai "European Enlightenment". Pada zaman ini seluruh Pandangan Alam (worldview) Barat telah bermuara hanya kepada kepentingan kemanusiaan dan keduniaan semata, ${ }^{7}$ dan nilai-nilai tradisional yang bersumber pada kebenaran agama digantikan pada otonomi yang berfondasi pada moral.

Namun lain hal dengan Sekularisme yang berasumsikan segala sesuatu yang berimbuhan Isme pasti mau tidak mau akan mengartikan pemahaman jika itu adalah sebuah pemikiran. Jadi Naquib Al-Attas berasusmsi jika sekularisme adalah faham yang memberikan kebebasan manusia dari kefahaman yang bersandarkan pada agama dan unsur-unsur keruhanian. Membebaskan perjalanan sejarah manusia dari campur tangan takdir (destiny),

\footnotetext{
5 Choirul Fuad Yusuf, "Peran Agama dalam Masyarakat" (Universitas Indonesia, 2000), 25.

${ }^{6}$ Syed Naquib Al Attas, Islam dan Sekularisme, hlm 1920.

${ }^{7}$ Ibid.
}

serta mendorong manusia kearah kepercayaan terhadap makna suatu proses perubahan sejarah, yakni perubahan dari peringkat Kekanak-kanakan menuju kepada peringkat kedewasaan (enlightenment) dan kematangan pikiran manusia, serta perubahan yang menuntut manusia harus mampu bersikap dewasa untuk memikul tanggung jawabnya sendiri tanpa harus bergantung dan membebankan kepada agama. ${ }^{8}$

Lain hal dengan pemahaman George Jacob Holyoale pada tahun 1841 Istilah sekularisme secara historis Pada awalnya merupakan keleluasaan berfikir dalam bidang etika. Dengan demikian jelas bahwa sekularisme merupakan suatu sistem etika, yakni sistem yang menyodorkan mengenai prinsip- prinsip kehidupan tentang apa, bagaimana, dan harus kemana manusia hidup atau bagaimana seharusnya manusia itu bertindak dalam kehidupan sehari-hari. ${ }^{9}$

Untuk menilai klaim awal bahwa sekularisme berarti pemisahan negara dan agama antara dinawi dan akhirat, atau persisnya pemojokan agama dari ranah publik, para pakar banyak merujuk pada peristiwa kemunduran peran agama di Eropa, Seperti yang dikatakan diatas kemunduran Agama dan Tingkat elektabilitas kepercayaan terhadap Agama merosot tajam,. Peran moralitas agama tergantikan oleh etika-etika, ketersingkapan hal-hal yang dulu dianggap misterius kini terjelaskan bahkan bisa disaintifikan, Sekularisasi diteorisasikan oleh August Comte yang meyakini fase teologis $\rightarrow$ metafisis $\rightarrow$ saintifik sebagai sebuah keniscayaan yang akan dilalui manusia sebagai konsekuensi dari kemajuan. Begitu Pula oleh Emile Durkheim yang percaya bahwa progresivitas sejarah akan berdampak lahirnya sekularisme modern yang menggantikan agama. Tak luput raksasa sosiologi Max Weber, yang percaya bahwa proses rasionalisasi akan memperlemah peran agama, yang disebutnya sebagai kepudaran daya pesona agama berikut ciri corak

\footnotetext{
${ }^{8}$ Ibid.

9 Yusuf, "Sekularisasi dan Sekularisme Tinjauan Filsafati Mengenai Perubahan Persepsi Tentang Peran Agama dalam Masyarakat", 18.
} 
kepemimpinan kharismatik yang menopangnya bahkan apa yang tampak sulit dijangkau nalar juga dapat diatasi oleh kemajuan teknologi dan revolusi saintifik.

Kehadiran negara-bangsa meruntuhkan kekuasaan-kekuasaan tradisional yang berasal kekuasaan dari Tuhan atau Yang Ilahi.

\section{Demokrasi sebagai Pembunuh Sekulerisme.}

Jadi jika kita kaitkan isu penistaan Agama, peristiwa GNPF-MUI, dan Aksi Bela Islam yang melibatkan begitu banyaknya persfektip, terselip pemahaman yang bersifat fundamental $^{10}$ terhadap Negara yakni pemahaman jika Negara kita dinilai menganut paham sekulerisme. Alih-alih Negara berusaha mencoba dalam jalur yang netral justru masyarakat berpandangan lain, contohnya yang dikatakan dan diteriakan pada gelar aksi bela Islam III, dimana hasil dari perjuangan -perjuangan para pencari keadilan melalui hati nurani dan jalan Agama, dibuat kecewa dengan kebijakan Negara yang selalu bersifat humanist dan Jugde of law.

Nah, inilah yang dikhawatirkan oleh banyak kalangan ketika Negara ingin bersikap netral namun kenyataannya seolah mendikotomikan dua kutub besar yakni Agama dan Negara, memang saya mengakui jika Negara memiliki nilasi dan Asas yang perlu di perhatikan dan begitupun Agama.

Dalam kasus yang melibatkan jutaan orang turun ke jalan ini berasumsikan bahwa semangat keberagamaan begitu besar di Negara ini walaupun pemerintah selalu mengidentifikasi Agama sebagai penyimbolan belaka.

Aksi bela Islam rupanya tidak berhenti di aksi bela islam I, aksi bela Islam berjenjang

\footnotetext{
${ }^{10}$ Disini arti Fundamental dalam bahasa Filsafat adalah berfikir mendasar dan mengakar, dalam hal ini Fundamental bukan disematkan kepada mereka yang berhaluan keras dan bertindak kasar, namun dalam pemahaman Filsafat Fundamental sesuatu yang wajar ketika seorang manusia atau komunitas yang memiliki pola fikir yang mendasar dan mengakar hingga bias dipertahankan, Menurut kamus Bahasa Indonesia: fundamental/fun·da·men·tal/ /fundaméntal/ a bersifat dasar (pokok); mendasar: iman merupakan suatu hal yang sangat -- di dalam kehidupan manusia
}

hingga yang terakhir aksi bela Islam $\mathrm{V}$ pada tanggal 21 februari 2017.

Pada akhirnya semangat Islam dan Jihad yang membara mesti terhempas dengan keputusan yang masih belum menjerat terpidana Basuki Cahaya Purnama yang waktu itu dituduh sebagai Penista Agama, akan tetapi Negara mendapat apresiasi yang begitu luar biasa karena cara Negara menyikapi aksi tersebut.

Aksi bela islam pada tanggal 14 Okober 2016 adalah semangat panggilan jihad dan semangat keruhanian yang menggetarkan Dunia dengan Jutaan manusia yang turun ke jalan layaknya lautan manusia Jakarta dikepung oleh masa dari berbagai penjuru kota, demi satu tujuan yakni penjarakan Penista Agama, Negara seolah lebih melindungi satu orang dibanding mendengarkan jutaan umat muslim yang menuntut. ${ }^{11}$ Inilah dia bukti jika agama tidak bias mencampuri urusan Pemerintahan dan Hukum.

Namun sebelumnya isu agama selalu kalah dengan issue-isue lainnya di negeri kita, sekarang pasca terjadinya Aski Bela Islam isu agama dalam sebuah pergerakan kembali diperhitungkan seolah menenggelamkan stigma yang berpandangan agama sumber Teroris.

Negara dibuat terkapar dalam hal ini terbukti jika pada akhirnya Presiden sebagai kepala tertinggi di pemerintahan langsung melakukan safari ke setiap ormas Islam dan para Tokoh Islam yang ada di Indonesia. Kendati demikian tetap saja tidak bisa disebutkan jika Negara kita mulai terbuka untuk mendengarkan jeritan kaum Agamawan yang ada malah di buat seakan dikonflikan antara satu pemahaman dan pemahaman yang lainnya, dari satu ormas dengan Ormas yang lainnya hingga menjadi sebuah konflik yang di pelihara oleh Negara, seperti halnya pasca Aksi bela Islam tidak sedikit tokoh Islam dianggap sebagai dalang makar dengan dalih agama, maka yang terjadi adalah pengKriminalisasi an para tokoh ormas tersebut contoh saja dari Ormas FPI, dan berakhir

11 http://www.voa-islam.com/topic/54/aksi-bela-islam123/\#sthash.NZrbSYCc.dpbs diunduh pada tanggal 16 Maret 2017 pukul 18:00 WIB. 
bentrokan dengan Ormas yang ditenggarai oleh salah satu pejabat tinggi lembaga keamanan (Polisi).

Bentrokan ini terjadi setelah sidang penistaan lambang Negara Pancasila oleh satu Aktor besar Aksi bela Islam Habib Rizieq Sihab.

Hal semacam ini memang tidak bisa di elakan lagi di Negara kita karena agama seolah dipisahkan dari Negara, yang di pakai Negara adalah Agama sebagai Symbol, makanya tidak heran nilai kesalehan dari para pemimipin dan pejabatnya tidak tercermin dalam mengolah dan mengatur tata kelola pemerintahan dan yang sangat bukti nyata adalah ketimpangan politik dan Ekonomi hingga melahirkan sebuah pemahaman ketidak sejahteraan masyarakat.

Menilik dari kasus ini nilai Demokrasi atau nilai kerakyatan seolah hilang ditelan bumi.

\section{Aksi Bela Islam Merupakan Cerminan Modernisme dalam Islam}

Islam adalah salah satu agama yang terbuka untuk setiap perubahan tanpa merubah inti dari nilai keislaman itu sendiri, modernism dalam islam juga tidak diharamkan seperti hal nya Sekulerisme dan Demokrasi.

Justru dalam islam Modernisme itu mesti terus dirawat, Aksi bela islam adalah hasil dari perkembangan dunia Modern jika tidak ada pemahaman modernism mungkin tidak akan terjadi Aksi bela islam yang begitu dahsyat hingga menggerakan jiwa masyarakat Islam.

Media Sosial adalah hasil dari Modernisme dalam bidang tekhnologi, namun bukan hanya itu Islam juga mesti memiliki pola pikir yang modern juga karena jika tidak memiliki pola pikir tersebut maka modernitas tidak akan pernah terjadi dan yang mungkin akan berkembang adalah ortodoks ${ }^{12}$

Modernism dalam islam tentunya bukan hal itu saja melainkan sebuah faham, Istilah "modern" berasal dari kata Latin modernus yang artinya "baru saja; just now". Pengertian modern mengacu bukan hanya kepada "zaman" (kita mengenal pembagian zaman menjadi zaman purba, zaman pertengahan dan

\footnotetext{
12 Ortodoks mengandung arti terbelakang
}

zaman modern), tetapi yang lebih penting mengacu kepada "cara berfikir dan bertindak". Peradaban modern ditandai oleh dua ciri utama, yaitu rasionalisasi (cara berfikir yang rasional) dan teknikalisasi (cara bertindak yang teknikal). Tumbuhnya sains dan teknologi modern diikuti oleh berbagai inovasi di segenap bidang kehidupan. Berbicara modern selalu berkaitan dengan masalah ruang dan waktu. Sesuatu bisa saja dikatakan modern di tempat tertentu, namun belum tentu ditempat lain. Begitu juga sesuatu bisa dikatakan modern untuk waku yang akan datang. Dan begitu seterusnya selalu membutuhkan sesuatu yang baru dari tradisitradisi yang lama. Bagi penulis modern mempunyai makna yang relatif. Namun berbeda ketika berbicara modernisme dalam arti pemikiran, tentunya tidak bisa dilepaskan dari alam pikiran Barat, karena akar-akarnya berasal dari perkembangan ilmu filsafat serta ilmu pengetahuan dan teknologi dari Barat.

Pada awal abad 15-16 muncul gerakan Renaisance, yaitu gerakan menentang gereja yang dianggapnya telah membelenggu dan memasung kreatifitas berfikir manusia, yang pada gilirannya manusia menempati kedudukan sentral dengan kekuatan rasionalnya, dimana pada masa ini Rene Descrates muncul sebagai tokoh utamanya. ${ }^{13}$

Modernisasi secara implikatif, merupakan proses yang cenderung mengikis dan menghilangkan pola-pola lama dan kemudian memberinya pola-pola baru, ${ }^{14}$ Islam merupakan rahmat bagi seluruh alam yang mempunyai nilai-nilai universal yang menyangkut semua manusia. Islam yang berarti sikap pasrah, kepatuhan dan ketundukan kepada Allah merupakan sikap umum yang dimiliki oleh setiap penganutnya. Islam sesuai dengan jiwanya selalu menerima perkembangan, karena Al Qur'an itu sendiri merupakan wahyu Tuhan yang bersifat universal dan upto-date memenuhi tuntutan perkembangan zaman. Universalisme Islam tergambar pada

\footnotetext{
${ }^{13}$ Lantip, Paham-paham Yang Menggoda Kehidupan Beragama, (Surabaya: Fakultas Ushuluddin, 1990)

14 Pardoyo, Sekularisasi Dalam Polemik, (Jakarta: Pustaka Utama Grafit, 1993), 40
} 
prinsip-prinsip nilai yang dapat diterapkan dalam kehidupan modern. ${ }^{15}$

Berkaca pada Aksi Bela islam maka tidak heran inilah kebangkitan umat Muslim di Indonesia sebagai bentuk perubahan pola pikir umat islam dalam menyikapi kesewenang wenangan pemerintah, dalam Aksi itu sebenarnya sarat muatan Modernisme yakni masyarakat dan umat mulai bisa meraba dan memilah mana yang baik dan mana yang salah, menjadi semakin dewasa.

Namun bukan hanya sisi positif yang terjadi ketika modernism berkembang dan mencoba merebahkan sayapnya sisi negatif adalah setelah terjadinya Aksi bela Islam tersebut muali muncul yang disebut HOAX, HOAX adalah isu yang dikembangkan lewat media masa online Atau berita yang belum tentu kebenarannya.

Masih banyak contoh di era sekarang ini bagaimana Modernisme diterima oleh Islam dan dianggap sebagai salah satu partner dalam hal penyebaran ajaran di era Global, Pemakaian kata modern atau modernism, atau Modernsasi selama ini sudah sangat populer dan semua kalangan intelektual muslim maupun Non Muslim sekalipun nampaknya sudah paham dengan peristilahan yang dimaksud. Ungkapan kata itu terkait dengan makna- makna tertentu yang bisa sama tapi bisa juga berbeda sesuai dengan aksentuasi masalah, tujuan dan asumsi peristilahan yang digunakan terutama dalam pengambilan istilah tersebut. Sedangkan Modern dalam peristilahan Arab dikenal dengan kata Tajdid yang artinya dalam bahasa Indonesia diartikan dengan pembaharuan. Dalam konteks pemikiran modern dalam Islam, ia merupakan suatu wacana yang mengawali perubahan mendasar bagi Islam sebagai suatu nilai ajaran dan umatnya sebagai pembuat arus perubahan tersebut. Tatkala mula pertama Islam lahir, untuk manusia telah berada di tepi jurang kehancuran karena tenggelam dalam lumpur keterbelakangan dan kebiadaban yang tak kenal moral, nilai dan kesopanan. Pelita perang dan petunjuk jalan kemana mereka

15 Dr. Quraish Shihab, Membumikan Al-Quran (Bandung: Mizan, 1996), 60 harus melangkah, secara biadab merka tinggalkan dan digantikan dengan keprcayaan dalam bentuk ritual yang dipalsukan oleh pemimpin kejahiliaan yang haus akan kekuasaan. Disebutnya zaman kegelapan karena mereka tidak tahu perintah dan larangan, tidak tau kompas sebagai pedoman, kemana harus melangkah, kemana tujuan harus berjalan kapan sampai dan harus berhenti ${ }^{16}$

Sebenarnya konsep modernism dalam islam begitu lama dikumandangkan bahkan beberapa keterangan dan sumber menyatakan jika konsep modernism Islam adalah konsep Pembaharuan. Sebagimana contoh dalam pemahaman pembaruan, bisa dilihat dengan apa yang dilakukan Ibnu Taimiyah (728 H/1328 M.) selaku reformasi salafisme yang menitik beratkan pada arti pengembalian orisinalitas pemahaman dan praktik Islam kepada kajian literal Al-Qur'an dan Sunnah ${ }^{17}$ begitu juga Muhammad bin Abdul Wahab (1703 M) selaku pembaru di bidang keagamaan justru mengabaikan rasionalitas intelektual menurut kajian pengetahuan modern, meski gagasan pendobrakan terhadap taklid, bid'ah dan khurafat sangat revolusioner dikumandangkannya, dengan berpegang teguh pada Al-Qur'an dan Sunnah. ${ }^{18}$

Pada terminologi mutakhir, diperlukan kekayaan tematis agar bisa mengupayakan penunjang dari ide ide modernism dalam islam, termasuk didalamnya perlu iptek secara integral dan komprehensif yang tidak melupakan akar dari nilai-nilai Islam itu sendiri, selama ini IPTEK selalu dikesampingkan dalam peradaban Islam mungkin karena disebabkan dampak sari sekularisme yang diatas kita bicarakan Oleh karenanya pembaruan yang muncul dalam studi-studi

16 Imam Munawwir, Kebangkitan Islam, (Surabaya: Bina Ilmu, 1984), 21

${ }^{17}$ Lihat pandangan Nurcholish Majid terhadap Ibnu Taimiyah yang di anggapnya termasuk pembaharu Islam kritis, dalam Kazanah Intelektual Islam, (Jakarta: Bulan Bintang 1985). hal.6

18 Mendalami pemikiran Muhammad bin Abdul Wahab, maka di anjurkan membaca bukunya, Kitab Al-Tauhid,( ITB Bandung: Pustaka Salman, 1985. yang secara sistematis mencirikan alur pemikiran beliau. 
modernisme di negara-negara Islam di penghujung abad ke 18 dan awal abad ke 19 banyak memunculkan tema-tema sentral tentang perlunya iptek sebagai pemikat perluasan citra peradaban umat Islam menapaki abadabad selanjutnya. Sehingga ada kecenderungan lebih semangat untuk proses Islamisasi sains, yang di Barat saat ini seakan sains bebas nilai dari keikutsertaan agama memberikan masukan positif di dalamnya. ${ }^{19}$

\section{SIMPULAN}

Fenomena yang terjadi pada masyarakat Islam di Indonesia yaitu tindakan membela Islam merupakan simbol munculnya semangat kebangkitan islam, sebagai suatu gerakan mematahkan gerakan sekularisme yang menyapu. banyak negara dengan mayoritas penduduk Islam.

\section{DAFTAR PUSTAKA}

Dede Mulyanto "Bela Islam atau Bela Oligarki : Pertalian Agama Politik dan Kapitalisme di Indonesia”Pustaka Indoprogres, 2017. Sebuah pengantar.

George McT.Kahin"Menuju Masyarakat Egalitarian: tentang Revolusi Kemerdekaan" kumpulan artikel Mencari Demokrasi, institute Studi Arus Informasi, (PT Midas surya grafindo:199).

Lantip, Paham-paham Yang Menggoda Kehidupan Beragama, (Surabaya: Fakultas Ushuluddin, 1990).

Choirul Fuad Yusuf ,"Peran Agama Dalam Masyarakat" (Universitas Indonesia, 2000).

Yusuf, "Sekularisasi Dan Sekularisme Tinjauan Filsafati Mengenai Perubahan Persepsi Tentang Peran Agama Dalam Masyarakat, 18.

Pardoyo, Sekularisasi Dalam Polemik, (Jakarta: Pustaka Utama Grafit, 1993).

Dr. Quraish Sihhab, Membumikan Al Qur'an, (Bandung: Mizan 1996)

\footnotetext{
${ }^{19}$ Abdul Sani, Lintas Sejarah Pertkembangan Moderndalam Islam, (Jakarta: Rajagrafindo Persada, 1998), 2
}

Imam Munawwir, Kebangkitan Islam, (Surabaya: Bina Ilmu, 1984)

Nurcholish Majid , Kazanah Intelektual Islam, (Jakarta: Bulan Bintang 1985)

Muhammad bin Abdul Wahab, Kitab Al-Tauhid ,(ITB Bandung: Pustaka Salman, 1985)

Abdul Sani, Lintas SejarahPertkembangan Moderndalam Islam, (Jakarta: Rajagrafindo Persada, 1998).

\section{Internet:}

http://kbbi.web.id/agama di Unduh pada tanggal 16 Maret 2017, Pukul: 08:00 WIB. http://kbbi.web.id/sekuler diunduh pada Tanggal 16 Maret 2017, Pukul 18:00 WIB. http://www.voa-islam.com/topic/54/aksi-belaislam-123/\#sthash.NZrbSYCc.dpbs diunduh pada tanggal 16 Maret 2017 pukul 18:00 WIB. 